\title{
Nematode Parasites of Brazilian Piciformes Birds: a General Survey with Description of Procyrnea anterovulvata n. sp. (Habronematoidea, Habronematidae)
}

\author{
Roberto Magalhães Pinto ${ }^{+}$, J Júlio Vicente, Dely Noronha
}

\author{
Laboratório de Helmintos Parasitos de Vertebrados, Instituto Oswaldo Cruz, Av. Brasil 4365, 21045-900 \\ Rio de Janeiro, RJ, Brasil
}

Thirty species of nematodes recovered from Piciformes hosts are reported. Procyrnea anterovulvata n. sp. from Chelidoptera tenebrosa brasiliensis is described and compared to P. colaptes and $\mathrm{P}$. pileata. The considered morphometric parameters are mainly related to the ratio between length of the body/ distance of the vulva to the anterior end. It is approximately 1:0.5 in P. colaptes and P. pileata compared to 1:0.1 in the new species. The male of Synhimantus (Dispharynx) crassissima is described for the first time. Thelazia ( Thelaziella) spizaeti is revalidated and new records are reported for some species.

Key words: nematodes - Procyrnea anterovulvata n. sp. - new records - Piciformes - birds - Brazil

The nematodes identified during the present investigation parasitize a great number of hosts, distributed in four families of Piciformes birds.

This survey was scheduled to provide further data on morphometrics, host records and geographical distribution for the nematode parasites of jacamars, puffbirds, toucans and woodpeckers in Brazil.

\section{MATERIALS AND METHODS}

Seventy-four samples of nematodes, recovered between 1913 and 1963 in Brazilian North, Central and Southeastern regions during institutional scientific expeditions and deposited in the Helminthological Collection of the Oswaldo Cruz Institute (CHIOC), were studied. The number of examined specimens, according to host family is: BUCCONIDAE: 6 Chelidoptera tenebrosa brasiliensis Sclater; 3 Monasa nigrifrons nigrifrons (Spix); 5 Notharchus macrorhynchos swainsoni (G. R. Gray); 1 Nystalus chacuru chacuru (Vieillot); 11 Nystalus maculatus maculatus (Gmelin). GALBULIDAE: 2 Galbula ruficauda rufoviridis Cabanis. PICIDAE: 15 Celeus flavescens flavescens (Gmelin); 11 Celeus flavescens lugubris (Malherbe); 2 Celeus jumana jumana (Spix); 6 Phloeoceastes melanoleucos melanoleucos (Gmelin); 3 Phloeoceastes robustus (Lichtenstein); 1 Phloeoceastes rubricollis

${ }^{+}$CNPq research fellow Proc. no. 300374/80-1. Fax: 5521-260.4866

Received 7 November 1995

Accepted 6 May 1996 tracheolopyrus (Malherbe); 1 Picumnus cirratus maconelli Sharpe. RAMPHASTIDAE: 3 Pteroglossus aracari aracari L.; 3 Ramphastos tucanus tucanus $\mathrm{L}$.

Nematodes were preserved in Railliet \& Henry's solution $(0.85 \% \mathrm{NaCl}$ solution: $93 \mathrm{ml}$; formaldehyde: $5 \mathrm{ml}$; glacial acetic acid: $2 \mathrm{ml}$ ) and were processed for study as described elsewhere (Pinto et al. 1993).

Preparation of "en face" mounts was done according to Anderson (1958). Illustrations were prepared with a drawing tube connected to an Olympus light microcope. Measurements are in micrometers, unless otherwise indicated. NHR and NGD indicate New Host Record and New Geographical Distribution, respectively. Classification of the nematodes follow Anderson and Bain (1976), Chabaud (1975 a, b, 1978) and confirmation of the taxonomic status of the hosts was based on Pinto (1978) and Sick (1984).

\section{RESULTS \\ (Habronematoidea, Habronematidae, Habronematinae) \\ Procyrnea anterovulvata $\mathrm{n}$. sp.} ( Fig. 1 a-f )

Description: morphometrics based on five specimens, two males and three females.

Males (Fig. $1 \mathrm{~d}$, e): body 4.99-5.18 mm long, 150-160 wide. Mouth with two lips with three pedunculate papillae each, two small, lateral in the outer circle and one large, central in the inner; two interlabia present. Oral aperture nearly round. Buccal capsule with thick sclerotized lining, 32-39 long. Muscular and glandular esophagus 300-320 and $1.58-1.63 \mathrm{~mm}$ long, respectively. Nerve ring 


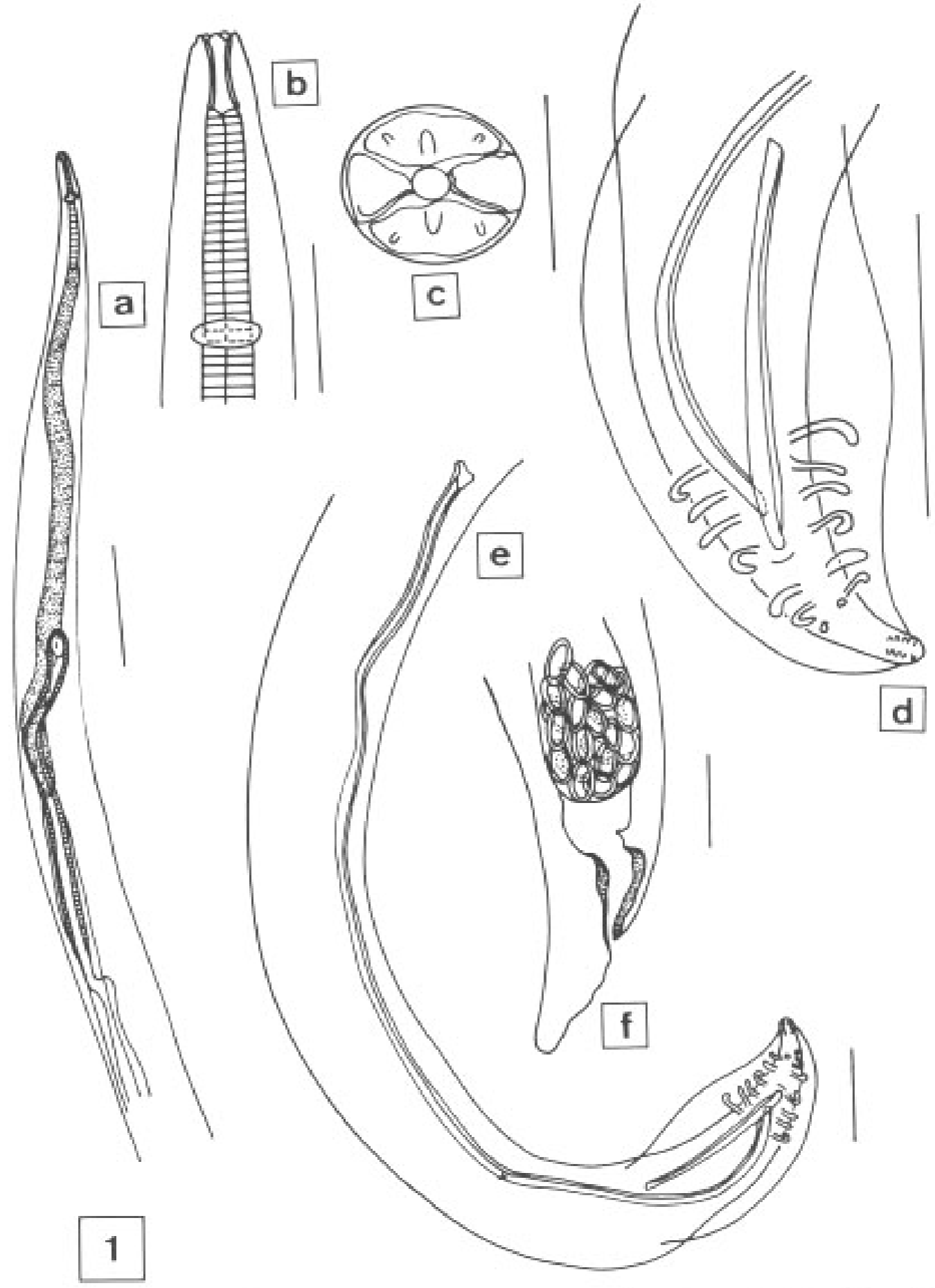

Fig. 1: Procyrnea anterovulvata $\mathrm{n}$. sp. - a: anterior portion of female, ventral view. b: anterior extremity of female, lateral view. c: head of female, en face view. d: posterior extremity of male, ventral view. e: posterior portion of male, ventro-lateral view. $\mathrm{f}$ : posterior extremity of female, lateral view. Bars: $0.02 \mathrm{~mm}$ in Fig. c; $0.1 \mathrm{~mm}$ in Figs b, d, f; $0.2 \mathrm{~mm}$ in Fig. e; $0.5 \mathrm{~mm}$ in Fig. a.

180 from anterior extremity. Excretory pore not observed. Left spicule slender, 1.56-1.62 mm long. Right spicule stouter, 240-270 long. Gubernaculum absent. Eleven pairs of pedunculate caudal papillae, of which four pairs are pre- and seven postcloacal, supported by large and prominent caudal 
alae. Cloacal aperture 110-130 from posterior extremity.

Females (Fig. 1 a, b, c, f ): body 12.24-12.75 $\mathrm{mm}$ long, 220-260 wide. Mouth and buccal capsule as in males; buccal capsule 39-46 long. Muscular and glandular esophagus 320-340 and 2.03$2.17 \mathrm{~mm}$ long, respectively. Nerve ring 180 from anterior extremity. Excretory pore not observed. Vulva 1.68-1.96 mm from anterior extremity. Vagina 1.54-1.68 mm long. Eggs 50-54 long, 28-32 wide. Anus 120-130 from posterior extremity.

Taxonomic summary

Type host: Chelidoptera tenebrosa brasiliensis; common name: swallow-wing ("andorinha, miolinho, urubuzinho")

Site of infection: gizzard

Type locality: Conceição da Barra, State of Espírito Santo, Brazil

Specimens studied: CHIOC no. 32,783 d (alotype), 32,783 a (holotype), 32,783 b, c, e, f (paratypes) (whole mounts); 14,811 (wet material).

Etymology: the specific name derives from the Latin anterior + vulva, meaning "which posseses the vulva in the anterior portion of the body".

\section{Remarks}

The species of Procyrnea Chabaud, 1975 present the vulvar aperture in the middle portion of the body (Chabaud 1958), slightly pre- or postequatorial. Nevertheless, the ratio between length of the body/distance of vulva to the anterior end is approximately 1:0.5 in all previously described species of the genus.

According to Chabaud and Brygoo (1958), two species of Procyrnea parasitize Piciformes hosts: $P$. colaptes (Walton, 1923) Chabaud, 1975, in which the above mentioned ratio is of 1:0.49-0.58 (present data) and P. pileata (Walton, 1928) Chabaud, 1975 with ratio of 1:0.47-0.59 (Walton 1928). Both species are reported from USA, parasitizing Colaptes auratus luteus Bangs and Hylotomus pileatus, respectively (Walton 1923, 1928, Cram 1927).

Procyrnea anterovulvata $\mathrm{n}$. $\mathrm{sp}$. is compared to these two species based on the high specificity of this group of nematodes to this order of birds. In the new species the ratio between lenght of body/ distance of the vulva to the anterior end is of 1:0.13-0.15, clearly distinguishing $P$. anterovulvata n. sp. from P. colaptes and P. pileata, as well as from the other species actually included in the genus. Moreover, the right spicule in males of $P$. anterovulvata $\mathrm{n}$. $\mathrm{sp}$. is remarkably shorter (240270) in comparison with the observed in $P$. colaptes and $P$. pileata (390-410 and 440, respectively).
(Acuarioidea, Acuariidae, Acuariinae)

Synhimantus (Dispharynx) crassissima (Molin,

1860) Chabaud, 1975

( Fig. 2 a-c )

Morphometrics: based on seven specimens, four males and three females, recovered from Ramphastos t. tucanus.

Description: males (Fig. 2 b ): body 6.51-8.62 $\mathrm{mm}$ long, 220-300 wide. Mouth with two large papilliform lips. Oral aperture oval-elongate, near of which derives two pairs of cephalic cordons. Buccal capsule 120-170 long. Cephalic cordons thick, markedly flexed, strongly recurrent, not anastomosing, 730-770 long. Muscular and glandular esophagus $680-720$ and $2.03-2.45 \mathrm{~mm}$ long, respectively. Nerve ring 280-300 from anterior extremity. Excretory pore not observed. Left spicule slender, 460-500 long. Right spicule stouter, 190210 long. Gubernaculum absent. Ten pairs of pedunculate caudal papillae, of which four are preand six post-cloacal, supported by narrow caudal alae. Cloacal aperture 210-270 from posterior extremity.

Redescription: females (Fig. 2 a, c): body 7.65$9.53 \mathrm{~mm}$ long, 570-580 wide. Mouth and oral aperture as referred for the males. Buccal capsule 140180 long. Cephalic cordons as referred for the males, 680 long. Muscular and glandular esophagus 510-680 and 1.96-2.38 mm long, respectively. Nerve ring 280-300 from anterior extremity. Excretory pore not observed. Vulva in posterior part of the body, 570-930 from posterior extremity. Ovijector 210 long. Eggs 39-43 long, 25-28 wide. Anus 120-160 from posterior extremity.

Taxonomic summary

Hosts: Chelidoptera tenebrosa brasiliensis NHR; Notharchus macrorhynchus swainsoni (= Bucco swainsoni); common name: spotted puffbird ("macuru") - NHR; Ramphastos t. tucanus (= Ramphastos monilis); common name: red-billed toucan ("tucano de peito branco, quirina, piapouco") - NHR

Other Piciformes host: Ramphastos vitellinus Lichtenstein, according to Cram (1927)

Site of infection: gizzard

Localities: Angra dos Reis, State of Rio de Janeiro; Belém, State of Pará; and Engano, State of Espírito Santo, Brazil

Specimens studied: CHIOC no. 32,778, 32,779 ab, 32,780 a-h (whole mounts).

\section{Remarks}

This species was originally described as Dispharagus crassissimus in 1860 from a Brazilian toucan based on female specimens and was redescribed by Cram (1927) as Dispharynx 
crassissima also considering female specimens only. Males were referred as "unknown" by both authors. The present data refer to the first description of male of this species.

(Seuratoidea, Seuratidae, Seuratinae)

Skrjabinura spiralis Gnédina, 1933

Taxonomic summary

Host: Galbula ruficauda rufoviridis; common name: rufous-tailed jacamar ("beija-flor grande, cuitelão") - NHR

Site of infection: intestine

Locality: Salobra, State of Mato Grosso do Sul, Brazil

Specimen studied: CHIOC no. 32,777 (whole mount).

Remarks

This species was referred in other hosts than Piciformes and its taxonomic status had also been discussed by Pinto et al. (1994), when Skrjabinura magnum (Johnston \& Mawson, 1941) Mawson, 1960 was proposed as a junior synonym of $S$. spiralis, reported parasitizing Falconidae birds in Brazil.

(Subuluroidea, Subuluridae, Subulurinae) Subulura travassosi Barreto, 1918

Taxonomic summary

Hosts: Chelidoptera tenebrosa brasiliensis, Monasa n. nigrifrons; common name: blackfronted nunbird ("bico de brasa") - NHR; Notharchus macrorhynchos swainsoni - NHR; Nystalus c. chacuru (= Bucco chacuru); common name: white-eared puffbird ("joão-bobo, dormião, jacuru, paulo-pires"); Nystalus m. maculatus; common name: spot-backed puffbird ("bico de latão") - NHR

Other Piciformes hosts: Bucco collaris Lath., B. rufiventris Natt., B. t. tamatia Gm, Malacoptila torquata (Hahn \& Kust), Monasa atra (Bodd.), $M$. m. morphoeus (Hahn \& Kust), M. nigra (Müller), Nonnula $r$. rubecula (Spix), Notharchus $m$. macrorhynchos (Gmelin), N. t. tectus (Bodd.), Nystalus s. striolatus (Pelz.), according to Barreto (1919).

Site of infection: intestine

Localities: Angra dos Reis, State of Rio de Janeiro; Cachimbo, State of Pará; Conceição da Barra, State of Espírito Santo; Salobra and Bodoquena, State of Mato Grosso do Sul; Ilha Seca and Rincão, State of São Paulo, Brazil

Specimens studied: CHIOC no. 3,299, 4,981, $6,166,11,742,11,775,11,776,12,589,12,595$, $12,596,12,628,13,051,13,282,14,782,14,793$, $14,837,15,596,20,937,21,420,21,441$ (wet material).
(Thelazioidea, Thelaziidae, Thelaziinae)

Thelazia (Thelaziella) spizaeti Strachan, 1957

(Fig. 2 d-f)

Taxonomic summary

Host: Pteroglossus a. aracari; common name: black-necked aracari ("araçari”) - NHR

Site of infection: orbital cavity

Locality: Raul Soares, State of Minas Gerais, Brazil

Specimens studied: CHIOC no. 32,782 a-c (whole mounts).

Remarks

Thelazia spizaeti, proposed from Spizaetus ornatus (Daudin), a Brazilian accipitrid hawk (Strachan 1957), is revalidated herein. It was considered a synonym of $T$. (Thelaziella) aquilina Baylis, 1934 by Anderson and Diaz-Ungria (1959) that may have misunderstood reliable morphometric data on $T$. (T.) spizaeti, mainly those related to the spicules. In $T$. (T.) aquilina they are 0.17-0.18 and $1.7-2.0 \mathrm{~mm}$ long, compared to 0.14 and 0.24 $\mathrm{mm}$ in $T$. (T.) spizaeti.

This extreme variation in the spicular ratio (1: 1.7-10.0) should not be considered an interspecific variation even though the specimens have been recovered from different hosts.

Procyrnea colaptes (Walton, 1923) Chabaud, 1975

Taxonomic summary

Hosts: Celeus flavescens lugubris; common name: pale-crested woodpecker ("pica-pau amarelo") NHR; C. j. jumana; common name: chestnut woodpecker ("pica-pau castanho") - NHR

Site of infection: gizzard

Locality: Salobra, State of Mato Grosso do Sul, Brazil-NGD

Specimens studied: CHIOC no. 32,785 a-i (whole mounts), 11,605, 12,778, 20,705 (wet material).

Remarks

Comments on this species are under the "Remarks" for Procyrnea anterovulvata $\mathrm{n}$. $\mathrm{sp}$.

Procyrnea pileata (Walton, 1928) Chabaud, 1975

Taxonomic summary

Hosts: Celeusf. flavescens; common name: blondcrested woodpecker ("pica-pau amarelo") - NHR; C. flavescens lugubris - NHR; C. j. jumana - NHR; Phloeoceastes m. melanoleucos; common name: crimson-crested woodpecker ("pica-pau real") NHR; P. robustus; common name: robust woodpecker ("pica-pau, pinica pau") - NHR; $P$. rubricollis trachelopyrus; common name: rednecked woodpecker ("pica-pau do peito 

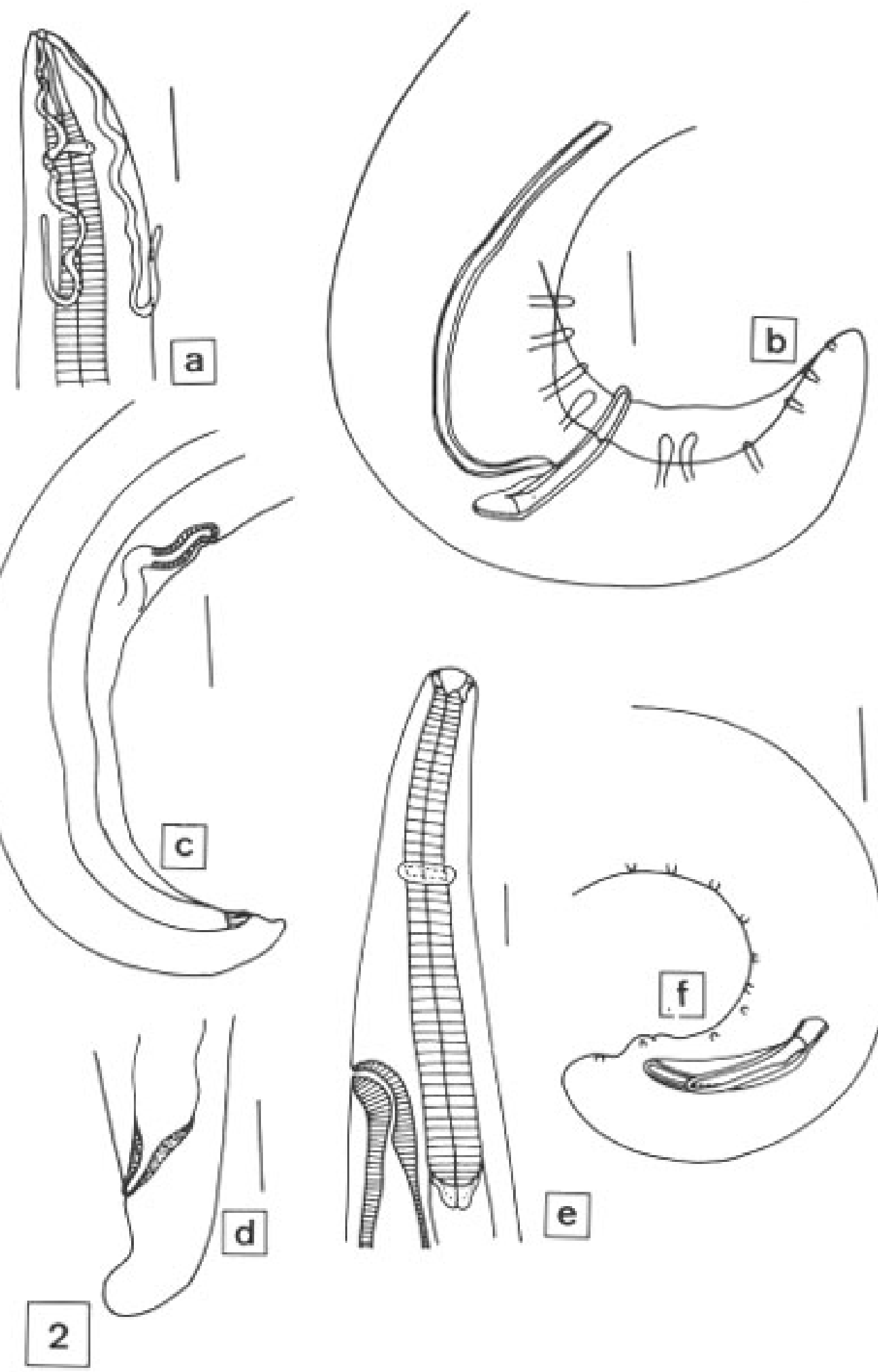

Fig. 2: Synhimanthus (Dispharynx) crassissima - a: anterior extremity of female, ventral view. b: posterior portion of male lateral view. c: posterior portion of female, lateral view. Thelazia (Thelaziella) spizaeti - d: posterior extremity of female, lateral view. e: anterior portion of female, lateral view. f: posterior portion of male, lateral view. Bars: $0.1 \mathrm{~mm}$ in all Figs. 
vermelho") - NHR; Picumnus cirratus maconelli; common name: white-barred piculet ("picapauzinho barrado") - NHR; Ramphastos t. tucanus NHR

Site of infection: gizzard

Localities: Angra dos Reis, State of Rio de Janeiro; Belém and Cachimbo, State of Pará; Salobra, State of Mato Grosso do Sul; Soóretama, State of Espírito Santo, Brazil - NGD

Specimens studied: CHIOC no. 32,781 a-c, 32,786 a-b (whole mounts), 5,386, 5,424, 13,020, $13,064,13,310,13,486,20,535,20,536,29,481$, 29,483 (wet material).

\section{Remarks}

Comments on this species are under the "Remarks" for Procyrnea anterovulvata n. sp.

(Diplotriaenoidea, Diplotriaenidae, Dicheilonematinae)

Hamatospiculum insigne (Schneider, 1866) Skrjabin, 1916

Taxonomic summary

Hosts: Celeus f. flavescens - NHR; Phloeoceastes robustus - NHR

Site of infection: body cavity

Localities: Barranco Alto, State of Mato Grosso do Sul; Engano and Soóretama, State of Espírito Santo, Brazil

Specimens studied: CHIOC no. 32,784 (whole mount); 14,859, 15,575 (wet material).

\section{Remarks}

This species, the type of the genus, has been reported in Picus sp. from Brazil and Paraguay. It was properly figured by Yorke and Maplestone (1926) based on Skrjabin (1916).

( Filarioidea, Onchocercidae, Dirofilariinae ) Pelecitus circularis (Molin, 1860) Railliet \& Henry, 1910

Taxonomic summary

Host: Phloeoceastes m. melanoleucos - NHR

Site of infection: among tendons of feet

Locality: Salobra, State of Mato Grosso do Sul, Brazil

Specimens studied: CHIOC no. 11,514, 13,019 (wet material).

\section{Remarks}

Pelecitus circularis, recently redescribed (Pinto et al. 1993), has been referred in a few Brazilian birds other than Piciformes (Bartlett \& Greiner 1986).

Pelecitus helicinus (Molin, 1860) Railliet \& Henry, 1910

Taxonomic summary

Host: Pteroglossus a. aracari - NHR
Other Piciformes hosts: Campephilus melanoleucos (Gmelin), Campylorhamphus procurvoides (Lafrenaye), Ramphastos tucanus $\mathrm{L}$. and Veniliornis passerinus olivinus (Natterer \& Malherbe), according to Bartlett and Greiner (1986)

Site of infection: among tendons of feet Locality: Raul Soares, State of Minas Gerais, Brazil

Specimens studied: CHIOC no. 20,064 (wet material)

Remarks

Pelecitus helicinus is a very common species, parasitizing a wide range of avian hosts. Morphometric data on this nematode have been recently reported (Pinto et al. 1993).

Procyrnea sp.

Taxonomic summary

Hosts: Chelidoptera tenebrosa brasiliensis, Celeus flavescens lugubris, C. j. jumana

Site of infection: gizzard

Localities: Belém, State of Pará; Salobra and Bodoquena, State of Mato Grosso do Sul; Ilha Seca, State of São Paulo, Brazil

Specimens studied: CHIOC no. 11,497, 11,587, $11,634,11,679,12,444,12,779,13,004,13,178$, 13,484, 15,021 (wet material).

\section{Remarks}

The specimens could not be specifically identified due to their poor state of preservation.

$$
\text { Synhimantus (Dispharynx) sp. }
$$

Taxonomic summary

Host: Veniliornis passerinus olivinus; common name: little woodpecker ("pica-pau pequeno")

Site of infection: gizzard

Locality: Angra dos Reis, State of Rio de Janeiro, Brazil

Specimens studied: CHIOC no. 10,425 (wet material).

\section{Remarks}

The specimens could not be specifically identified due to their poor state of preservation.

(Aproctoidea, Aproctidae, Aproctinae) Aprocta sp.

Taxonomic summary

Hosts: Phloeoceastes robustus, Pteroglossus a. aracari

Site of infection: body cavity

Locality: Barranco Alto, State of Mato Grosso do Sul; Soóretama, State of Espírito Santo, Brazil Specimens studied: CHIOC no. 15,568, 29,482 (wet material). 
Remarks

The specimens could not be specifically identified due to their poor state of preservation.

(Filarioidea,Onchocercidae, Splendidofilariinae) Splendidofilaria sp.

Taxonomic summary

Host: Nystalus m. maculatus

Site of infection: body cavity
Locality: Salobra, State of Mato Grosso do Sul, Brazil

Specimens studied: 32,787 a-b (whole mounts)

Remarks

The specimens could not be specifically identified due to their poor state of preservation.

The nematode species presently reported as well as those previously referred in Brazilian Piciformes hosts are included in Table.

TABLE

Nematodes from Piciformes birds in Brazil

Parasite species
Aprocta sp.
*Capillaria columbae (Rudolphi, 1819)
*C. venusta Freitas and Mendonça, 1958

*Cerastospira thriponaxis Wehr, 1930

*Dessetfilaria braziliensis (Yeh, 1932)

*Dicheilonema fusiformis (Molin, 1858)

*Diplotriaena sp.

*Eulimdana micropenis (Trav., 1926)

*Habronema unilateralis (Molin, 1860)

Hamatospiculum insigne

* Oxyspirura anacanthura (Molin, 1860)

*O. sygmoidea (Molin, 1860)

*Paronchocerca ibanezi (Freitas, Vicente and Pinto, 1970)

Pelecitus circularis

$P$. helicinus

Procynea anterovulvata $\mathrm{n} . . \mathrm{sp}$.

P. colaptes

P. pileata

Procyrnea sp.

Skrjabinura spiralis

* Splendidofiilaria gedoelsti Trav., 1926

Splendidofilaria sp.
Host species

Phloeoceastes robustus

Ramphastos toco Muller

Petroglossus a. aracari $L$.

$P$. aracari wiedii Sturm

Ramphastos toco Muller

$R$. vitellinus ariel Vigors

$R$. c. culminatus Gould

$R$. dicolorus $L$

Monasa tranquila (?)

Celeus flavescens lugubris

Tripsurus flavifrons (Vieill.)

Selenidera maculirostris (Lich.)

S. maculirostris

Ramphastos monilis Muller

Celeus $f$. flavescens

Phloeoceastes robustus

Ramphastos c. culminatus

$R$. toco cuvieri Wagler

Colaptes campestris (Vieill.)

Phloeceastes $m$. melanoleucos

Campephilus melanoleucos

Campylorhampus procurvoides

Pteroglossus a. aracari

Ramphastos tucanus

Veniliornis passerinus olivinus

Chelidoptera tenebrosa brasiliensis

Celeus flavescens lugubris

C. j. jumana

C. f. flavescens

C.f. lugubris

C. j. jumana

Phloeoceastes $m$. melanoleucos

$P$. robustus

P. rubricollis tracheolopyrus

Picumnus cirratus maconelli

Ramphastos tucanus

Chelidoptera tenebrosa brasiliensis

Celeus flavescens lugubris

C. j. jumama

Galbula ruficauda rufoviridis

Selenidera maculirostris

Nystalus m. maculatus 
* Subulura strongylina (Rud., 1819)

Subulura travassosi

\author{
Bucco melanoleuchus (?) \\ B. collaris \\ B. rufiventris \\ B. t. tamatia \\ Chelidoptera tenebrosa brasiliensis \\ Malacoptila torquata \\ Monasa atra \\ M. m. morphoeus \\ M. nigra \\ M. n. nigrifrons \\ Nonnula r. rubecula \\ Notharchus m. macrorhynchos \\ $N$. macrorhynchos swainsoni \\ N. t. tectus \\ Nystalus c. chacuru \\ N. m. maculatus \\ N. s. striolatus \\ Chelidoptera tenebrosa brasiliensis \\ Veniliornis passerinus olivinus \\ Notharchus m. macrorhynchos \\ Melanerpes $f$., flavifrons (Vieill.) \\ Pteroglossus a. aracari \\ $R$. toco cuvieri Wagler \\ Pteroglossus a. aracari
}

* Not found during the present study. Data after Yamaguti (1961), Freitas et al. (1970), Anderson and Bain (1976), Vicente et al. (1983), Bartlett et al. (1985), Bartlett and Bain (1987).

\section{ACKNOWLEDGEMENTS}

To Mara Lucia de Souza Lemos, IOC research fellow from the "Setor de Programação Visual (CICT/ FIOCRUZ)" for technical support concerning the figures presented.

\section{REFERENCES}

Anderson RC 1958. Méthode pour l'examen des nématodes en vue apicale. Ann Par hum comp 33: 171-172.

Anderson RC, Bain O 1976. Keys to the genera of the order Spirurida. Diplotriaenoidea, Aproctoidea and Filarioidea. p. 59-116. In RC Anderson, AG Chabaud, S Willmott (eds). CIH Keys to the nematode parasites of vertebrates 3. Part 3. Commonwealth Agricultural Bureaux, England.

Anderson RC, Diaz-Ungria C 1959. Revision preliminar de las especies de Thelazia Bosc (Spiruroidea: Thelaziidae), parasitas de aves. Mem Soc Ci Nat La Salle 19: 37-75.

Barreto ALBB 1919. Revisão da subfamília Subulurinae Travassos, 1914. Mem Inst Oswaldo Cruz 11: 1-70.

Bartlett CM, Bain O 1987. New avian filarioids (Nematoda: Splendidofilariinae): Dessetfilaria guianensis gen. n. sp. n., Andersonfilaria africanus gen. n., sp. n., and Splendidofilaria chandenieri sp. n. Proc Helminthol Soc Wash 54: 1-14.

Bartlett CM, Greiner EC 1986. A revision of Pelecitus Railliet \& Henry, 1910 (Filarioidea, Dirofilariinae) and evidence for the "capture" by mammals of filarioids from birds. Bull Mus natn Hist nat Paris 4th ser. 8: 47-99.
Bartlett CM, Wong PL, Anderson RC 1985. Eulimdana lari (Yamaguti, 1935) n. comb. (Nematoda: Filarioidea) from Phalaropus spp. (Charadriiformes) in Canada and a review of the genus Eulimdana Founikoff, 1934. J Can Zool 63: 666-672.

Chabaud AG 1958. Essai de classification des nématodes Habronematinae. Ann Par hum comp 33: 445-508.

Chabaud AG 1975a. Keys to the genera of the order Spirurida. Camallanoidea, Dracunculoidea, Gnathostomatoidea, Physalopteroidea, Rictularioidea and Thelazioidea. p. 1-27. In RC Anderson, AG Chabaud, S Willmott (eds). CIH Keys to the nematode parasites of vertebrates 3. Part 1. Commomwealth Agricultural Bureaux, England.

Chabaud AG 1975b. Keys to the genera of the order Spirurida. Spiruroidea, Habronematoidea and Acuarioidea. p. 29-58. In RC Anderson, AG Chabaud, S Willmott (eds). CIH Keys to the nematode parasites of vertebrates 3. Part 2. Commomwealth Agricultural Bureaux, England.

Chabaud AG 1978. Keys to the genera of the superfamilies Cosmocercoidea, Seuratoidea, Heterakoidea and Subuluroidea. p. 1-71. In RC Anderson, AG Chabaud, S Willmott (eds). CIH Keys to the nematode parasites of vertebrates 6 . Commomwealth Agricultural Bureaux, England.

Chabaud AG, Brygoo ER 1958. Sur un nouveau nématode habroneme, parasite de rapaces, a Madagascar. Mem Inst Sci Madagascar 12: 127-138.

Cram EB 1927. Bird parasites of the suborder Strongylata, Ascaridata and Spirurata US Nat Mus Bull 140: 1-465. 
Freitas JFT, Vicente JJ, Pinto RM 1970. Sobre uma filária prodelfa parasita de ave. Atas Soc Biol Rio de Janeiro 12 (Supl.): 39-42.

Pinto OMO 1978. Novo catálogo de aves do Brasil 1. Empresa Gráfica da Revista dos Tribunais, São Paulo, 446 pp.

Pinto RM, Vicente JJ, Noronha D 1993. Nematode parasites of Brazilian psittacid birds, with emphasis on the genus Pelecitus Railliet \& Henry, 1910. Mem Inst Oswaldo Cruz 88: 279-284.

Pinto RM, Vicente JJ, Noronha D 1994. Nematode parasites of Brazilian accipitrid and falconid birds (Falconiformes). Mem Inst Oswaldo Cruz 89: 359-362.

Sick H 1984. Ornitologia brasileira, uma introdução. 1. Universidade de Brasília, 474 pp.

Skrjabin KI 1916. Contributions à l'étude de la faune helminthologique du Paraguay. I. Nématodes. $J$
Russe Zool 1: 736-757.

Strachan AA 1957. Eye worms of the family Thelaziidae from Brazilian birds. Can J Zool 35: 179-187.

Vicente JJ, Pinto RM, Noronha D 1983. Estudo das espécies brasileiras do gênero Diplotriaena Henry \& Ozoux, 1909 (Nematoda, Filarioidea). Mem Inst Oswaldo Cruz 78: 165-182.

Walton AC 1923. Some new and little known nematodes. J Par 10: 60-73.

Walton AC 1928. A revision of the Leidy Collection. Proc Acad Nat Sci Philadelphia 79: 49-163.

Yamaguti S 1961. Systema Helminthum 3. The nematodes of vertebrates. Parts 1 and 2. Interscience Publishers, New York, 1261 pp.

Yorke W, Maplestone PA 1926. The nematode parasites of vertebrates. J A Churchill (eds), London, $536 \mathrm{pp}$. 
